\title{
Molecular typing tools for identifying and characterizing lactic acid bacteria: a review
}

\author{
Anshul Sharma ${ }^{1,2} \cdot$ Sulhee Lee $^{3} \cdot$ Young-Seo Park $^{4}$ (1)
}

Received: 1 May 2020/Revised: 21 July 2020/Accepted: 24 July 2020/Published online: 16 August 2020

(C) The Author(s) 2020

\begin{abstract}
Identification and classification of beneficial microbes is of the highest significance in food science and related industries. Conventional phenotypic approaches pose many challenges, and they may misidentify a target, limiting their use. Genotyping tools show comparatively better prospects, and they are widely used for distinguishing microorganisms. The techniques already employed in genotyping of lactic acid bacteria (LAB) are slightly different from one another, and each tool has its own advantages and disadvantages. This review paper compiles the comprehensive details of several fingerprinting tools that have been used for identifying and characterizing LAB at the species, sub-species, and strain levels. Notably, most of these approaches are based on restriction digestion, amplification using polymerase chain reaction, and sequencing. Nowadays, DNA sequencing technologies have made considerable progress in terms of cost, throughput, and methodology. A research journey to develop improved versions of generally applicable and economically viable tools for fingerprinting analysis is ongoing globally.
\end{abstract}

Young-Seo Park

ypark@gachon.ac.kr

1 Department of Food and Nutrition, Gachon University, Seongnam 13120, Republic of Korea

2 Faculty of Applied Sciences and Biotechnology, Shoolini University of Biotechnology and Management Sciences, Bajhol, Solan, Himachal Pradesh 173229, India

3 Research Group of Healthcare, Korea Food Research Institute, Wanju 55365, Republic of Korea

4 Department of Food Science and Biotechnology, Gachon University, Seongnam 13120, Republic of Korea
Keywords Lactic acid bacteria · Probiotics - DNA - RNA · Fingerprinting · Typing

\begin{tabular}{|c|c|}
\hline Abbreviations & \\
\hline AFLP & Amplified fragment length polymorphism \\
\hline ARDRA & $\begin{array}{l}\text { Amplified ribosomal DNA restriction } \\
\text { analysis }\end{array}$ \\
\hline Bif. & Bifidobacterium \\
\hline DGGE & Denaturing gradient gel electrophoresis \\
\hline ERIC-PCR & $\begin{array}{l}\text { Enterobacterial repetitive intergenic } \\
\text { consensus-PCR }\end{array}$ \\
\hline ESI & Electrospray ionization \\
\hline FLOW-FISH & $\begin{array}{l}\text { Flow cytometry-fluorescence in situ } \\
\text { hybridization }\end{array}$ \\
\hline Lac. & Lactococcus \\
\hline$L b$. & Lactobacillus \\
\hline Leu. & Leuconostoc \\
\hline MALDI-TOF & $\begin{array}{l}\text { Matrix-assisted laser desorption/ } \\
\text { ionization-time of flight }\end{array}$ \\
\hline MLST & Multilocus sequence typing \\
\hline MS & Mass spectrometry \\
\hline NGS & Next-generation sequencing \\
\hline$P$. & Pediococcus \\
\hline PFGE & Pulse field gel electrophoresis \\
\hline RAPD & Random amplified polymorphic DNA \\
\hline RFLP & Restriction fragment length polymorphism \\
\hline Rep-PCR & Repetitive extragenic palindromic PCR \\
\hline$S$. & Saccharomyces \\
\hline SNP & Single nucleotide polymorphism \\
\hline St. & Streptococcus \\
\hline TGGE & Temperature gradient gel electrophoresis \\
\hline WGS & Whole-genome sequencing \\
\hline
\end{tabular}




\section{Overview}

There is a growing interest in the identification of industrially relevant and beneficial microbial strains owing to their heterogeneity and ubiquitous nature. Simple morphological characterization of these microorganisms is ineffective in documenting a complete diversity profile (Tabssum et al., 2018). Over time, many typing tools, phenotypic or genotypic, have been documented; however, an effective tool is preferred to have high typeability and discriminatory power for the microorganisms that are under study (Ben Amor et al., 2007). Among the beneficial microbes, probiotics are live microorganisms, which confer health benefits on the host when administered in adequate amounts (FAO/WHO 2002). Probiotics have been found to have beneficial effects on human and animal health (Stefanis et al., 2016), and generally are some lactic acid bacteria (LAB), including Lactobacillus (Lb.) acidophilus, Lb. casei (recently reclassified as Lacticaseibacillus casei, Zheng et al., 2020), Lb. fermentum (recently reclassified as Limosilactobacillus fermentum, Zheng et al., 2020), Lb. helveticus, Lb. paracasei (recently reclassified as Lacticaseibacillus paracasei, Zheng et al., 2020), Lb. plantarum (recently reclassified as Lactiplantibacillus plantarum, Zheng et al., 2020), Lb. reuteri (recently reclassified as Limosilactobacillus reuteri, Zheng et al., 2020), Lb. rhamnosus (recently reclassified as Lacticaseibacillus rhamnosus, Zheng et al., 2020), Lb. salivarius (recently reclassified as Ligilactobacillus salivarius, Zheng et al., 2020), Lb. lactis subsp. cremoris, Lb. lactis subsp. lactis, Streptococcus (St.) thermophilus, and some bifidobacteria including Bifidobacterium (Bif.) animalis, Bif. bifidum, Bif. breve, and Bif. longum. Among the yeasts, Saccharomyces (S.) carlsbergensis, S. cerevisiae, S. lactis, and S. rouxii are also probiotic strains. Interestingly, some LAB strains are generally recognized as safe (GRAS) microorganisms. $\mathrm{LAB}$ are rod- or cocci-shaped Gram-positive bacteria with low $\mathrm{G}+\mathrm{C}$ content and common morphological, physiological, and metabolic characteristics (Wu et al., 2017). $\mathrm{LAB}$ are common inhabitants of the human gastrointestinal tract, and are omnipresent in fermented and unfermented foods. The wide range and number of applications of LAB make it necessary to associate genomic proof with their important features to exploit their metabolic applications (Stefanovic et al., 2017; Wu et al., 2017) and identify novel microorganisms at all taxonomic levels rapidly and precisely (Jarocki et al., 2016). Furthermore, there is a need for new starter species from the wild LAB pool for generating diverse food and pharmaceutical products that target human health (Sharma et al., 2020).

The identification and classification of LAB populations, based on traditional phenotypic, biochemical, and physiological tests, is well known. Classification of some new types of strains based merely on phenotypic characteristics has caused obscurities, which have eventually become fixed by means of molecular tools (Van Hoorde et al., 2008). Furthermore, it is extremely difficult to identify a bacterial strain using these approaches due to the several complicated procedures, different nutritional and growth needs of LAB, and lower discriminatory power (Østlie et al., 2004; Singh et al., 2009). Therefore, such inadequacies of the phenotypic tools led to the emergence of genotypic methods to classify LAB. The molecular typing tools can be broadly categorized as polymerase chain reaction (PCR) amplification-, DNA-, and sequencing-based tools (Ranjbar et al., 2014). Furthermore, a critical step for the molecular documentation of LAB is choosing the appropriate genetic marker or gene that can be used for PCR amplification to discriminate the LAB species (Pogačić et al., 2010). The major advantage of the DNA-based methodologies is that they accurately identify the strains.

DNA sequencing skills have made significant strides in the past decade in terms of price per reaction and user handiness. Nonetheless, phenotypic tools are important for the initial classification of formerly unidentified LAB species. Overall, a polyphasic approach that integrates several lines of evidence should be used to acquire a comprehensive account of a new LAB species.

This review is aimed to summarize current knowledge on the molecular tools that are used to identify and characterize several bacterial species, including $\mathrm{LAB}$ and probiotic strains. Exemplary studies, based on these tools for typing of LAB or probiotic strains, have also been included. Furthermore, this paper briefly includes the advantages and disadvantages of each fingerprinting method.

\section{Types of molecular tools}

Since the mid-1980s, the plethora of various molecular techniques has been widely applied to characterize probiotic or LAB species. Each technology has its own strengths, usefulness, and drawbacks. Notably, there is no single method that can provide all the information on the inter- and intra-species differentiation. Therefore, the current strategy is to follow a multiphasic approach to identify and characterize LAB strains correctly. Contrary to phenotypic approaches, molecular tools are faster and far more dependable and reproducible, and can even differentiate among closely related species, which are otherwise phenotypically indistinguishable. 
Fig. 1 Schematic diagram for Ribotyping (A) and amplified ribosomal DNA restriction analysis

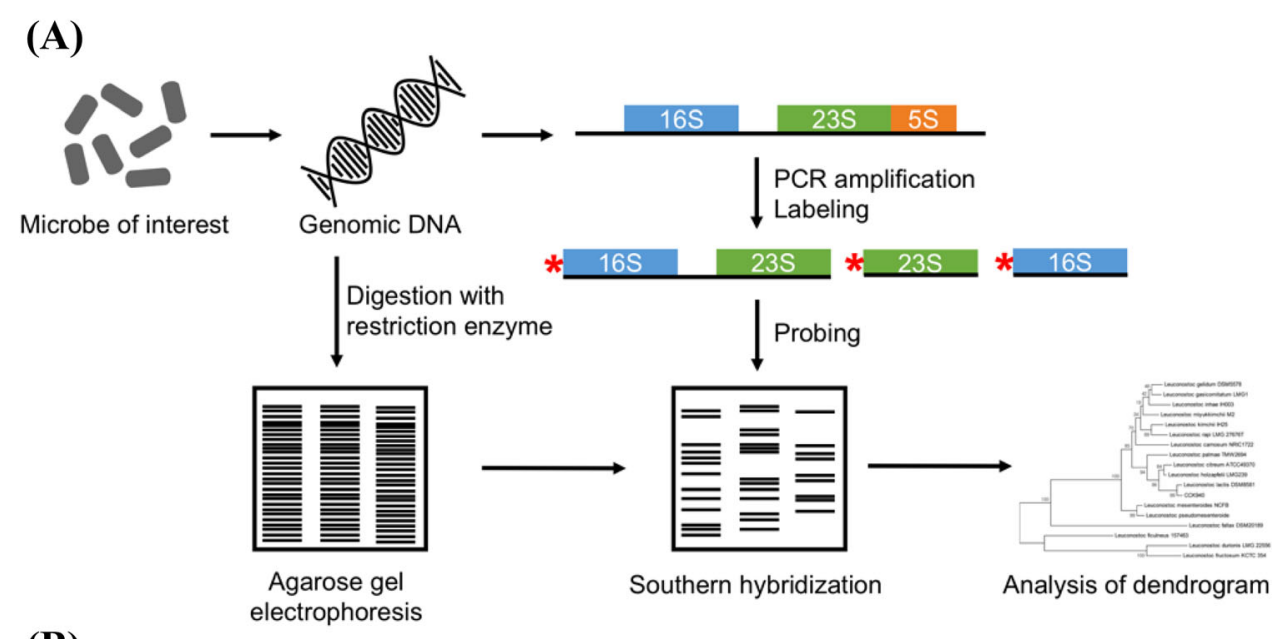

(B)
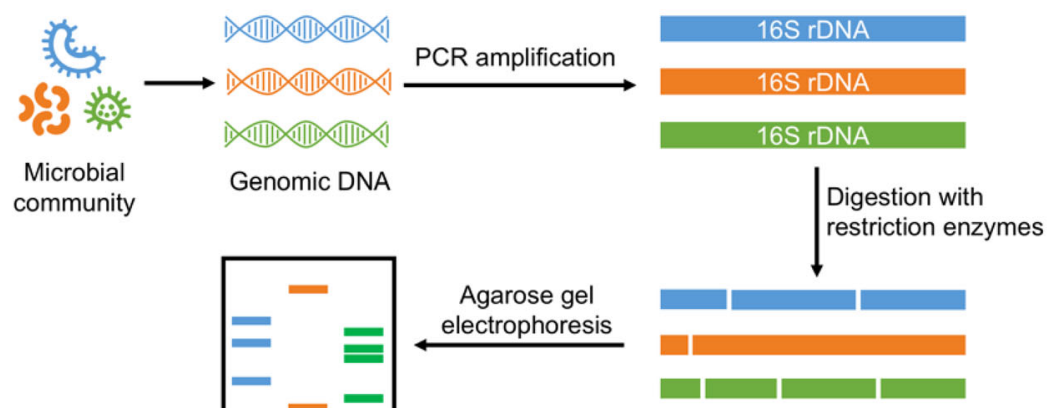

Analysis of digestion pattern

\section{Ribotyping}

In this approach, ribosomal genes present within the bacterial genome are recognized using nucleic acid probes. This combined detection is based on the digestion of genomic DNA of the microbe of interest with restriction endonuclease and Southern hybridization using rDNA cistrons (16S, 23S, and 5S rRNA genes) as the labeled probes (Fig. 1(A)). The ribotyping probes range from partial sequences of the rDNA genes or their spacer regions to the full rDNA operon (Stefanis et al., 2016). Particularly, the intergenic space region between the $16 \mathrm{~S}$ rDNA and $23 \mathrm{~S}$ rDNA shows high polymorphism. Higher discriminatory power is obtained in those situations in which multiple ribopatterns are used for each ribotype, especially when restriction enzymes with particular recognition sequences are used. Nevertheless, ribotyping is more suitable for distinguishing bacteria at the species and subspecies levels than at the strain level (Ben Amor et al., 2007).

The ribotyping tool was used to classify strains of Lactobacillus sp. obtained from commercial products and human fecal samples (Giraffa et al., 2000; Zhong et al., 1998). Ribotyping has been successfully applied for the discrimination of the Lb. casei, Lb. acidophilus, Lb. reuteri, Lb. sakei (recently reclassified as Latilactobacillus sakei,
Zheng et al., 2020), Lb. delbrueckii, Lb. plantarum, Lb. helveticus, Lb. rhamnosus, Lb. crispatus, Lb. fermentum, and $L b$. gasseri species at the species and strain levels, as reviewed previously (Singh et al., 2009). A previous study documented the use of a riboprinter (an automated tool) for characterizing and differentiating 91 strains of the $L b$. acidophilus and Lb. casei groups at the species level. The riboprinter tool was found to be fast, precise, and reproducible (Ryu et al., 2001).

The advantages of ribotyping include general applicability, reproducibility, and high discriminatory power. However, it is expensive, labor-intensive, and time-consuming. Using an automated riboprinter can be easier and faster, and it identifies microbial species in a shorter time span $(8 \mathrm{~h})$; hence, it significantly reduces the testing time.

\section{Amplified ribosomal DNA restriction analysis (ARDRA)}

ARDRA, a type of restriction fragment length polymorphism (RFLP), is a simple method, and technically, it is a variation of ribotyping (Stefanis et al., 2016). This technique works on the principle of digesting amplified ribosomal DNA with selected restriction endonucleases, which 
are capable of cleaving DNA at specific sequences, generating fragments of different lengths, and performing sizebased separation by agarose gel electrophoresis (Fig. 1(B)). In some cases, the fragments may be transferred to nitrocellulose or nylon membranes, and after that, specific probing and finally detection are performed. Deletions or insertions, mutations in restriction endonuclease sites, and the acquisition or removal of restriction endonuclease recognition sites may result in variations in the bacterial strains.

Recently, this technique was utilized to identify human gastrointestinal tract-originated 14 reference Lactobacillus species (Öztürk and Meterelliyöz 2015). Likewise, the $L b$. acidophilus group was identified in the crops of birds and typed (Hagen et al., 2003). Stenico et al. identified 13 Bifidobacterium species by RFLP analysis of the partial gene sequence of the heat shock protein (hsp60) at the species and subspecies levels (Stenico et al., 2014).

This technique is fast, easy, and cost-effective. The complexity of the banding profiles is the major limitation of this method. In addition, owing to this, multiple restriction endonucleases are required either separately or in combination to obtain the desired resolution. Besides, the technique displays low discriminatory power due to the comparatively conserved nature of the 16S rRNA genes. Additionally, the technique is less sensitive with respect to gel staining, and thus, it is utilized in populations with few bacterial species.

\section{Random amplified polymorphic DNA (RAPD)}

RAPD is a typing tool, which uses a single arbitrary primer of 20-25 base pairs (bps). This primer randomly hybridizes to different locations of chromosomal DNA sequences that show homology nearest to the that of the bacterial genome to detect polymorphisms (Williams et al., 1990). Variants of RAPD, based on the length of the primer, annealing temperature, and length of the protocol, include DNA amplification fingerprinting and arbitrarily primed PCR (Ranjbar et al., 2014). Agarose gel electrophoresis separates the amplification products to generate a bacterial fingerprint that is used to identify and characterize bacterial strains (Fig. 2(A)). When sequence information of the newly isolated strains is not accessible, RAPD analysis is first applied for the development of strain-specific primers (Plessas et al., 2017).

Weiss et al. used and identified RAPD patterns of the strains of $L b$. reuteri, a potential probiotic bacterium (Weiss et al., 2005). Similarly, the RAPD technique has been used for the characterization of different strains of the Lactobacillus, including Lb. plantarum (Galanis et al., 2015), Lb. brevis (recently reclassified as Levilactobacillus brevis, Zheng et al., 2020) (Sharma et al., 2016), Lb. acidophilus, and Lb. fermentum (Kakelar et al., 2019), and Bacillus species (Mohkam et al., 2016). Our research group recently found that RAPD could be used as a valuable tool for identifying Leuconostoc (Leu.) mesenteroides, Lb. brevis, and $L b$. plantarum from deliberately inoculated yogurt and a commercial probiotic powder (Sharma et al., 2016; Sharma et al., 2020). Additionally, Lb. paracasei K5 was identified from a Feta-type cheese using a multiplex PCR technique based on the RAPD analysis (Plessas et al., 2017).

Another study aimed to identify the enzymatic activities responsible for the degradation of biogenic amines in LAB. Through RAPD and 16S rRNA gene partial sequencing, different LAB strains, such as the Leuconostoc (Leu. mesenteroides and Leu. lactis), Lactobacillus (Lb. casei, Lb. paracasei, Lb. rhamnosus, Lb. parabuchneri (recently reclassified as Lentilactobacillus parabuchneri, Zheng et al., 2020), Lb. paraplantarum (recently reclassified as Lactiplantibacillus paraplantarum, Zheng et al., 2020), and Lb. fermentum), and Streptococcus species (St. thermophilus and St. gallolyticus), Lactococcus (Lac.) lactis, Pediococcus (P.) pentosaceus, Enterococcus lactis, and Weissella paramesenteroides, were identified (Guarcello et al., 2016). Our research group also identified Leu. mesenteroides, Lb. brevis, and Leu. citreum in different foods and food sources in Korea using RAPD markers (Kaur et al., 2017a; Sharma et al., 2016). The RAPD tool has been used for the characterization of Bifidobacterium strains, including Bif. bifidum, Bif. infantis, Bif. adolescentis, Bif. longum, Bif. animalis, and Bif. breve (Vincent et al., 1998).

The advantages of RAPD include good discriminatory power, general applicability, and fast, inexpensive, and easy performance (Ngoi et al., 2015). The discriminatory power can be enhanced by increasing the number of primers. Besides, this technique requires no prior knowledge of the target DNA sequence and a limited amount of bacterial DNA for amplification (Kaur et al., 2017a; Ranjbar et al., 2014). Poor reproducibility is the major drawback of this technique. Reproducibility depends on many factors, such as the quantity and quality of DNA, PCR buffer, primer concentration, and annealing temperature. It has been suggested that accurate optimization of the PCR protocol could overcome this problem (Manan et al., 2009). Besides, the use of triplet arbitrary primed-PCR at three different temperatures $\left(38,40\right.$, and $\left.42{ }^{\circ} \mathrm{C}\right)$ has been advocated. Furthermore, primer hybridization at non-specific locations may give rise to false-positive results. 
Fig. 2 Schematic diagram for random amplified polymorphic DNA (A) and amplified fragment length polymorphism (B)

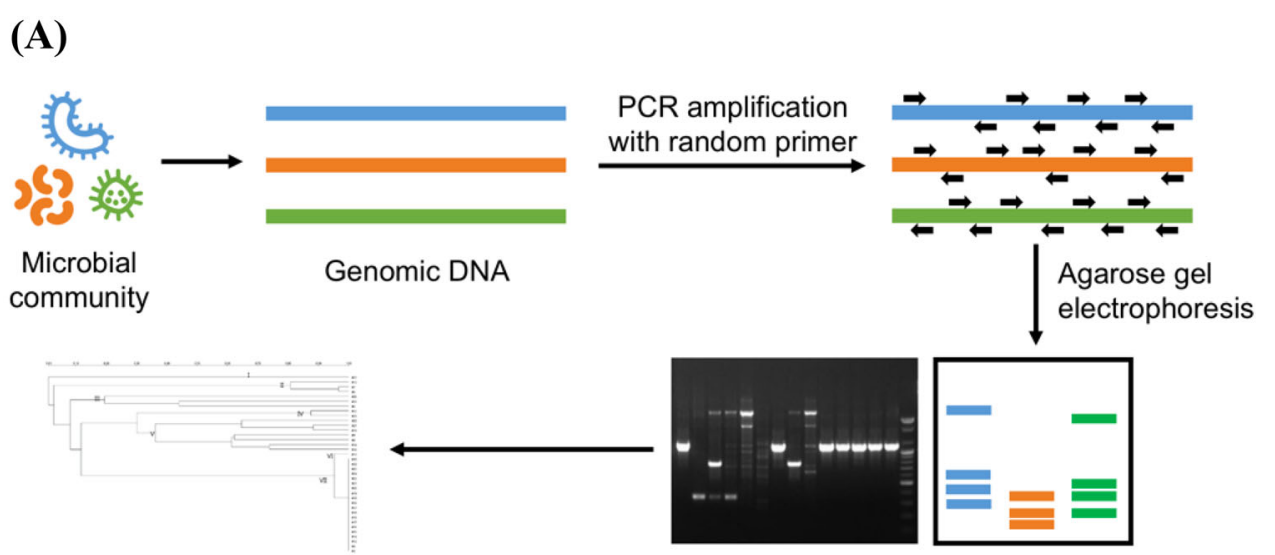

Analysis of dendrogram

(B)

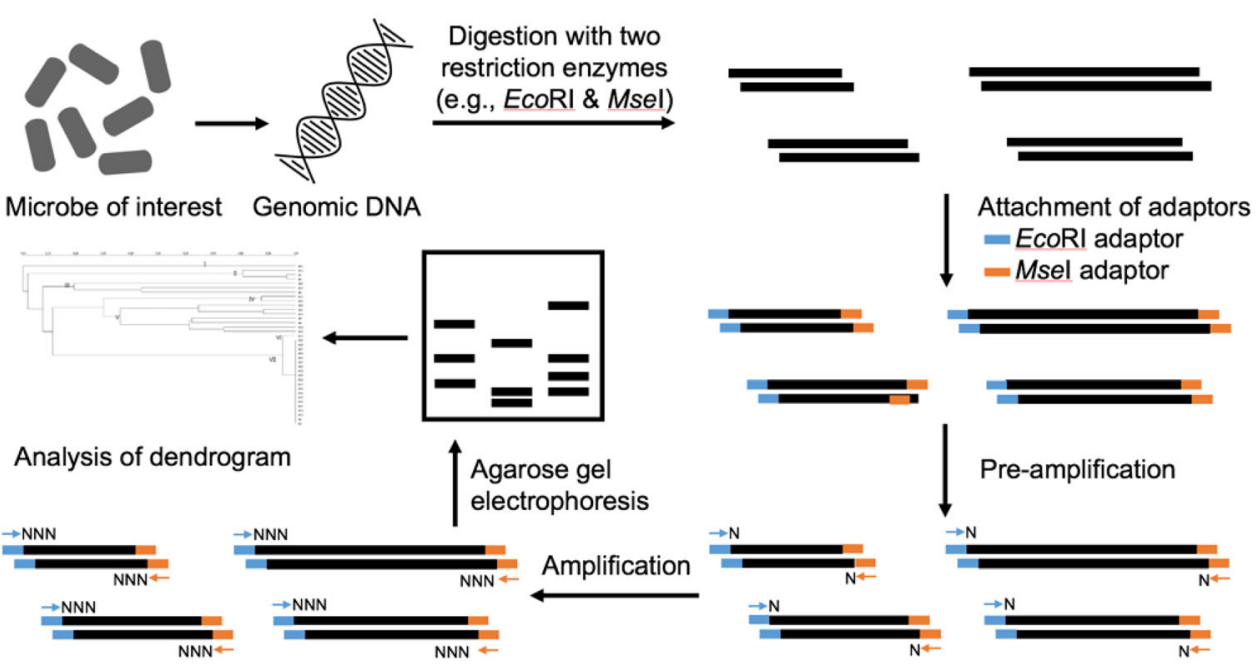

\section{Amplified fragment length polymorphism (AFLP)}

AFLP was originally used for the characterization of plant genomes, but it has become more common in the field of microbial typing over time. There are two AFLP versions, one with two separate restriction endonucleases and PCR amplification primers and the other with a single primer and restriction endonuclease.

AFLP is a combination of RFLP and PCR. The target DNA is digested with restriction endonucleases, as in RFLP, and ligated with primers, known as adapters, for PCR amplification (Fig. 2(B)). The mixture is subjected to selective amplification using a limited set of primers. For the digestion of genomic DNA, AFLP uses two restriction enzymes, a frequent cutter (e.g. MseI or TaqI) and rare cutter (e.g. EcoRI or PstI) (Vos et al., 1995). For selective amplification to reduce the number of amplicons after digestion with restriction endonuclease, the 3 '-ends of the PCR primers are modified by adding specific nucleotides (one to three). The pre-amplification (first) PCR is accomplished with first combinations that contain a single bp extension, while the selective (final) PCR amplification is achieved using primers with up to three bp extensions. These modified primers anneal to only DNA target fragments that have complementary sequences to the adaptors and modified nucleotides, allowing specific amplification. The amplified fragments undergo electrophoresis either on an agarose gel or with high resolution denaturing polyacrylamide gel with autoradiography (Vos et al., 1995). The fluorescent-labeled PCR primers have emerged as alternatives to radioactive material when an automated DNA sequencer is used. This approach offers high discriminatory power, resolution, and throughput (Giammanco et al., 2007; Ross and Heuzenroeder 2005).

The advantages of AFLP include higher reproducibility and sensibility and no requirement for prior knowledge of the sequence (Singh et al., 2009). The AFLP data are analyzed based on the presence or absence of polymorphism. This allows for a rapid scan of the entire genome for polymorphisms. The limitations of this technique include 
poor target DNA quality, complicated procedure with a large number of steps, expensive process, and the prerequisite of an automated DNA sequencer.

The AFLP technique has been effectively utilized for genotyping and intra-species documentation of LAB obtained from many fermented food products and the human gastrointestinal tract (Ben Amor et al., 2007). In a previous study, AFLP was used for differentiation of $L b$. plantarum, Lb. pentosus (recently reclassified as Lactiplantibacillus pentosus, Zheng et al., 2020), and Lb. pseudoplantarum at the species level (Giraffa and Neviani 2000). Bove et al. compared Lb. rhamnosus isolated from cheese grown in rich medium (MRS) and cheese-like medium (CB) using complementary DNA (cDNA) AFLP. The study established that gene profiles of $L b$. rhamnosus showed more diversity in $\mathrm{CB}$ than in MRS. The diverse gene expression levels in $\mathrm{CB}$ were plausibly due to the activation of different metabolic pathways to produce a high amount of energy (Bove et al., 2011). Another study showed that AFLP could be used as a tool to establish a correlation between the carbohydrate utilization capacities and niche/genotype adaptation of the Lb. rhamnosus species isolated from humans and food (Ceapa et al., 2015). Furthermore, a previous study differentiated many Lactobacillus strains at the intra-species level using fluorescent AFLP (fAFLP) (Vancanneyt et al., 2006). Another study designed oligonucleotide primers using a fAFLP-derived gene fragment (125 bps) that encoded the aldo/keto reductase enzyme for the species-specific PCR assay of $L b$. brevis (Fusco et al., 2016).

\section{Pulse field gel electrophoresis (PFGE)}

PFGE is a type of gel electrophoresis that separates large DNA molecules under pulsed-field conditions. PFGE is very similar to the typical gel electrophoresis technique. Agarose gel electrophoresis is incapable of effectively separating large DNA molecules (Chen and Gu 2018). Using PFGE, DNA fragments up to $800 \mathrm{~kb}$ in size can be resolved (Ranjbar et al., 2014).

Briefly, the bacterial DNA is immobilized into agarose blocks to avoid any mechanical damage to the DNA. Restriction endonuclease (rare cutter), which recognizes sequences of six-eight bps, digests the target DNA. Agarose blocks are placed into the migration gel wells after enzymatic digestion and subjected to an alternating pulse voltage gradient, resulting in a bacterial fingerprint (Fig. 3(A)). In PFGE, there is a periodic change in the electrical field orientation (Holzapfel et al., 2001). It is a gold standard method with good discriminatory power, reproducibility, and typeability (Chen et al., 2010). However, it is a labor-intensive and complicated procedure that demands skilled personnel for the analysis of the fingerprinting patterns (Neoh et al., 2019). In addition, this technique is prone to genetic instability, has minimal accessibility, and takes 3-4 d to complete (Wassenaar and Newell 2000).

PFGE has been efficaciously used for strain typing for the Bifidobacterium species, Lb. plantarum, Lb. sakei, Lb. acidophilus, Lb. casei, Lb. delbrueckii, Lb. fermentum, Lb. helveticus, and Lb. rhamnosus (Giraffa and Neviani 2000; Klein et al., 1998; Roussel et al., 1993; Roy et al., 1996; Sánchez et al., 2004). In a previous study, PFGE was found to be more discriminatory in identifying closely related $L b$. rhamnosus and $L$ b. casei strains than ribotyping or RAPD (Tynkkynen et al., 1999).

\section{Repetitive extragenic palindromic PCR (Rep- PCR)}

Rep-PCR has been widely applied for the typing of LAB strains. It works on the principle of producing highly specific genomic fingerprints by linking primers that correspond to interspersed repetitive specific DNA elements that are present at various locations within the LAB genome (Fig. 3(B)). PCR amplification of the distinct repetitive elements creates differently-sized DNA fragments that can be isolated by agarose gel electrophoresis, generating distinctive fingerprint patterns for different LAB strains ( $\mathrm{Fu}$ and $\mathrm{Li}$ 2014). To determine genetic similarity, the fingerprint patterns are compared with each other. The different types of primers are Rep-PCR, enterobacterial repetitive intergenic consensus-PCR (ERIC-PCR), extragenic repeating PCR (BOX)-PCR, and (GTG) $)_{5}$-PCR sequences (Gevers et al., 2001). A combined approach, including (GTG) $)_{5}$-PCR fingerprinting and AFLP, has been established as a useful tool for LAB strain typing (Van Hoorde et al., 2008).

The advantages of Rep-PCR are that it has a short analysis time and high discriminatory power, requires a small amount of DNA, and is a procedure that is inexpensive and suitable for all LAB strains (Ranjbar et al., 2014; Singh et al., 2009). Moreover, its discriminatory power relies on the type of primer and number of repetitive sequences present in the LAB strain (Woo et al., 2006). Variability in PCR reagents and cycles and the conditions of gel electrophoresis can affect the reproducibility of RepPCR (Fu and Li 2014).

Our lab has applied this molecular tool for the characterization of the Lb. brevis (Kaur et al., 2018), Leu. mesenteroides (Kaur et al., 2017b), and Leu. citreum (Kaur et al., 2017c) strains obtained from different food products and locations in South Korea. Lee et al. used Rep-PCR to differentiate several Lactobacillus strains, namely $L b$. 
Fig. 3 Schematic diagram for pulse field gel electrophoresis (A) and repetitive extragenic palindromic PCR (B)

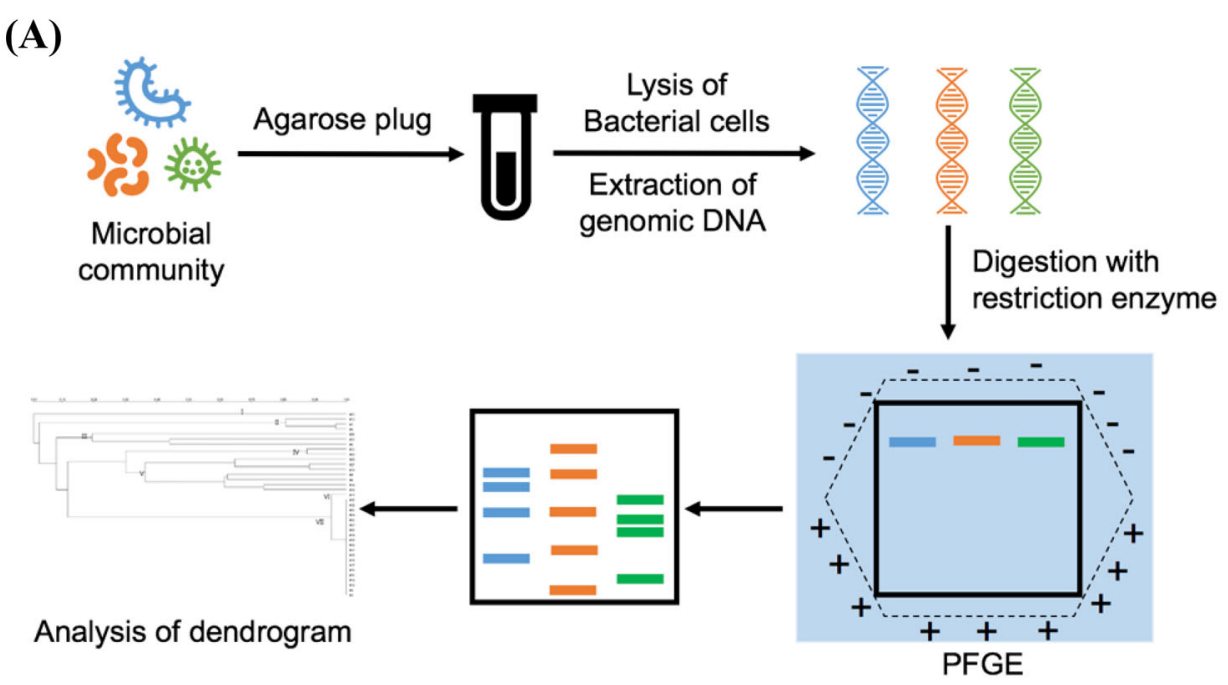

(B)
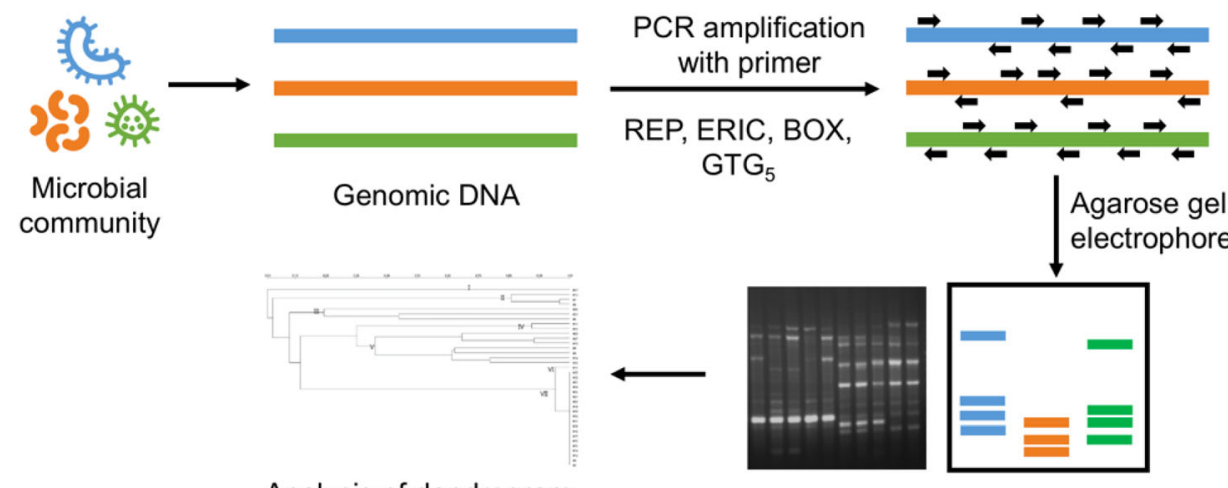

Agarose gel electrophoresis

Analysis of dendrogram brevis, Lb. salivarius, $L b$. reuteri, Lb. gallinarum, and $L b$. panis, at the strain level (Lee et al., 2012). Another study from Iran identified the probiotic strains in dairy products and Tarkhineh food using this approach (Tafvizi and Tajabadi Ebrahimi 2015). To identify bifidobacteria at the species, subspecies, and strain levels, BOXA1R primer has been proven to be a promising tool (Masco et al., 2003). Likewise, Jarocki et al. advocated that, in comparison to RAPD, ARDRA, and SDS-PAGE, BOX-PCR was found to be most effective in differentiating the Bifidobacterium strains at all taxonomic levels (Jarocki et al., 2016).

\section{Denaturing (D)/temperature (T) gradient gel electrophoresis (DGGE/TGGE)}

DGGE/TGGE is a culture-independent method, and primarily demonstrates the differences in DNA denaturation protocols. This tool has been used for the study and successive identification of specific bacterial species in a mixed bacterial population (Stefanis et al., 2016). The principle is based on the assumption that a denaturing or temperature gradient in polyacrylamide gel, which contains urea and formamide, can be used to separate 16S rDNA fragments of different sequences and similar or same lengths (Fig. 4(A)). Briefly, total DNA is extracted from a target bacterial population, and PCR is used to amplify the hypervariable regions within the $16 \mathrm{~S}$ rDNA gene (Dimitrov 2019). One primer (GC clamp with a varying length of 30 to $50 \mathrm{bps}$ and high GC content) is used to bind the denatured DNA fragments. The resulting PCR products are denatured based on their sequences since the GC-terminus is not denatured. The PCR products migrate to different locations in the gel owing to their unique melting patterns. The disparity in their DNA sequences is the reason for their varying melting profiles (Muyzer 1999). With proper selection of the analytical conditions and if the molecular weight of the PCR products is in the range of 200-600 bps, it is possible to differentiate PCR fragments even with a single nucleotide difference. Hence, the partly melted targets are separated due to the differences in their electrophoretic mobilities and visualized by staining. Ethidium bromide, SYBR Green I, and silver staining can be performed (Muyzer and Smalla 1998). For DGGE, the 
Fig. 4 Schematic diagram for denaturing gradient gel electrophoresis (A), terminal (T)-restriction fragment length polymorphism (B), and multilocus sequence typing $(\mathbf{C})$
(A)

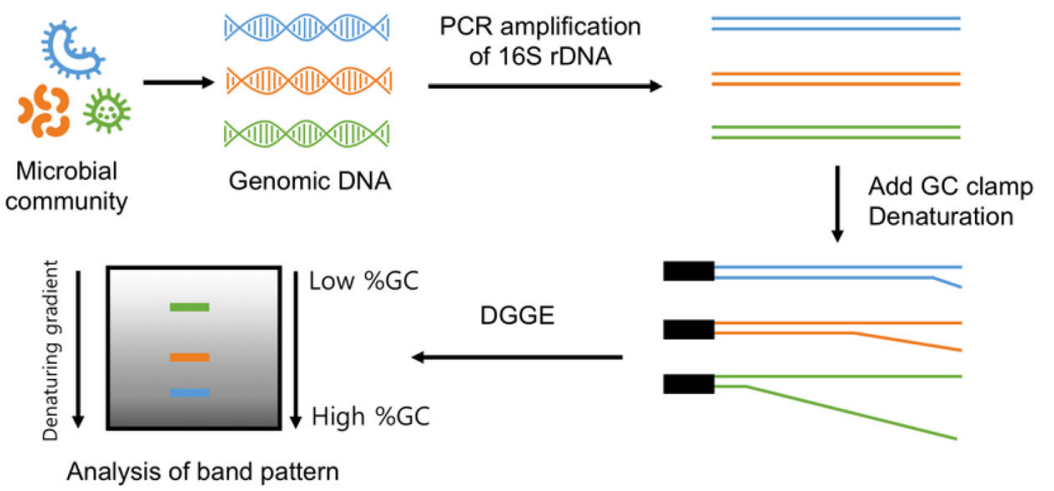

(B)
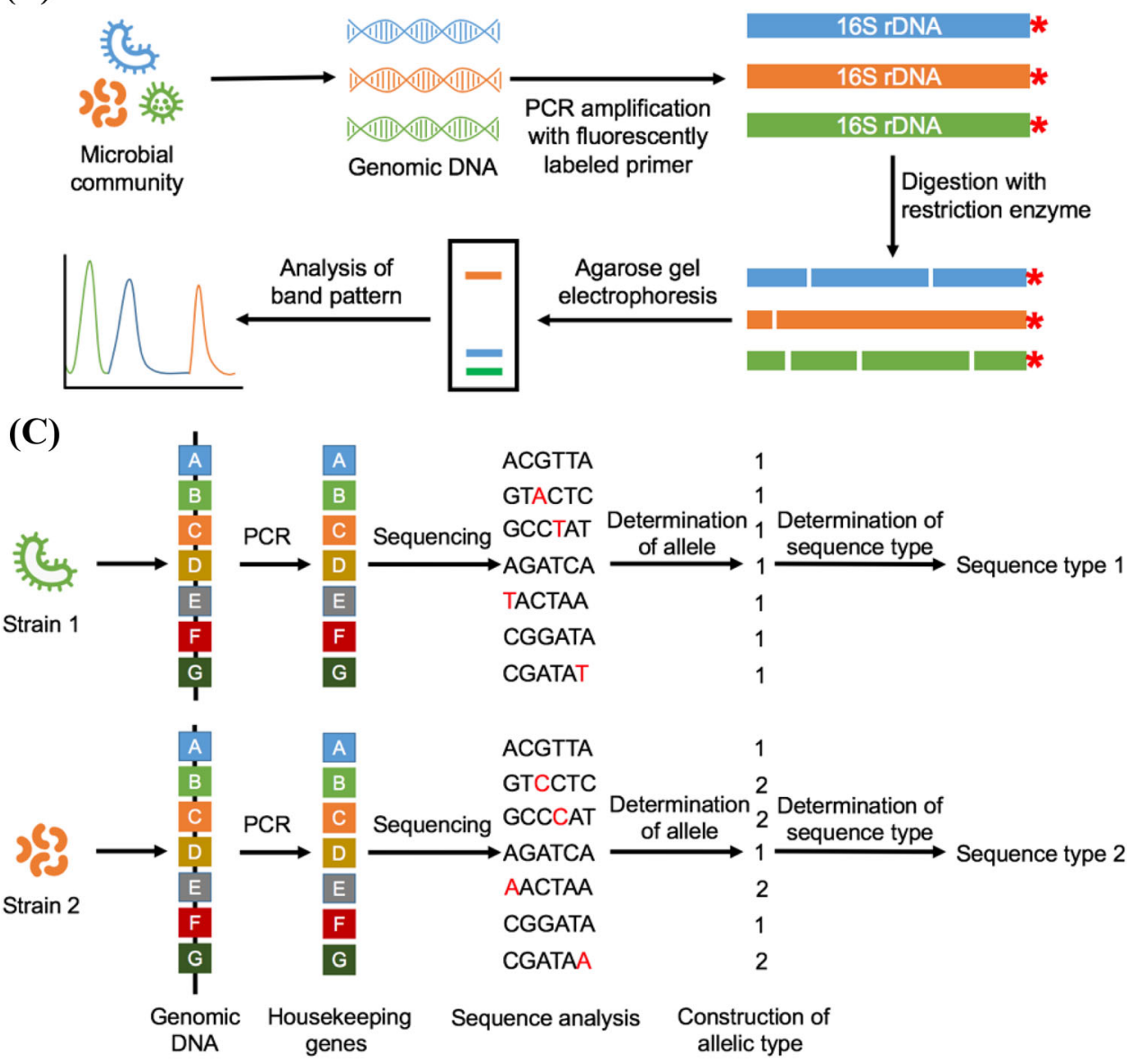

working temperature is maintained at $55{ }^{\circ} \mathrm{C}$ and $65{ }^{\circ} \mathrm{C}$, while for TGGE, the temperature varies over the time required to develop the denaturing gradient.

Since no cultivation of bacteria is required, DGGE has a great advantage over a number of other methods. The disadvantages include poor detection of bacteria that are present in insignificant numbers in a community and incorrect estimation of the bacterial diversity due to the detection of the heteroduplex formed by the heterogeneous rRNA operons.
Hong et al. identified Leu. mesenteroides, Leu. citreum, $P$. pentosaceus, and Leu. gelidum as dominant bacteria in kimchi by microflora analysis (Hong et al., 2016). This tool was used to confirm the presence of probiotic strains in naturally fermented lactic acid products (Liang et al., 2018). In another study, Lb. bulgaricus was identified in intestinal samples (Dimitrov 2019) and Lb. plantarum was identified in red wine (based on rpoB) (Spano et al., 2007) using PCR-DGGE. This technique has also been applied to identify non-conventional LAB species, including $L b$. frumentii, $L b$. acetotolerans, $L b$. pontis (recently 
reclassified as Limosilactobacillus pontis, Zheng et al., 2020), and Lb. fructivorans (recently reclassified as Fructilactobacillus fructivorans, Zheng et al., 2020) (Nishino et al., 2015; Wang et al., 2014; Wang and Nishino 2010; $\mathrm{Wu}$ and Nishino 2016). The identification of non-conventional $\mathrm{LAB}$ is required to elucidate their specific roles in various biological processes.

\section{Terminal $(T)$-restriction fragment length polymorphism (T-RFLP)}

The conventional RFLP technique has low resolution, and therefore, small restriction fragments cannot be identified (Wang et al., 2010). As a substitute for the conventional RFLP technique, T-RFLP, founded on the basic steps of RFLP, can be used. This method includes extraction of DNA or RNA, PCR amplification, enzyme digestion, and fragment identification (Stefanis et al., 2016). The PCR amplification of a specific gene is usually performed with fluorescent-labeled primers [e.g. fluorescein amidite (6FAM)], and it is followed by generation and separation of restriction fragments (usually four base cutter restriction enzymes are used) (Tabit 2016). The separated fluorescentlabeled terminal fragments of different sizes are determined using a DNA sequencer and analyzed by comparing either the bands or peaks of the T-RFLP runs to a database of known species (Fig. 4(B)). Similar to DGGE, T-RFLP is a nucleic acid-based tool that identifies specific microbial populations and develops a fingerprint of the microbial community. The strengths and shortcomings of this technique are identical to those of RFLP. This method is advantageous in providing a comparative bacterial profile of a sample of diverse bacteria. In addition, this technique does not require prior bacterial culturing for typing of a bacterial species from a mixed bacterial population (Tabit 2016). Additionally, profile accuracy can be increased by using more restriction enzymes.

In a previous study, the T-RFLP tool was used for identifying $\mathrm{LAB}$ at the species level during beverage fermentation (Bokulich and Mills 2012). Baniyah et al. used T-RFLP to assess the diversity of LAB in ileum broiler chicken. The study used restriction endonucleases $M s p \mathrm{I}$ and HaeIII. Prebiotic bran-supplemented commercial feed, compared to Rhizopus oryzae-fermented bran, displayed a higher LAB diversity in the ileum of the animals. The predominant LAB was found to be the Lactobacillus sp. and Lb. delbruecii subsp. bulgaricus (Baniyah et al., 2018).

\section{Multilocus sequence typing (MLST)}

MLST is a more effective tool for bacterial typing than the traditional 16S rRNA gene sequencing technique. MLST uses automated DNA sequencing, which involves the sequencing of internal fragments of the housekeeping gene loci (seven in number) of bacterial strains to characterize alleles (Maiden et al., 2013). The sequence of each fragment is compared with sequences (alleles) that were identified earlier at that locus, and allele numbers are assigned for the selected loci (Tanganurat et al., 2009). The combination of the seven genes governs the strain's allelic profile, and each separate allelic profile is allocated a sequence type, which is used to categorize the target strain (Fig. 4(C)).

The MLST technique has been used to detect genetic differences in Lb. plantarum (de las Rivas et al., 2006; Xu et al., 2015), St. thermophiles (Delorme et al., 2017), the Lb. casei group (Bao et al., 2016; Diancourt et al., 2007; Feng et al., 2018), and Oenococcusoeni (De Las Rivas et al., 2004; Yu et al., 2018). Our research group used the MLST tool to differentiate the Leu. mesenteroides, Leu. citreum, and Lb. brevis strains (Sharma et al., 2017; Sharma et al., 2018a; Sharma et al., 2018b). MLST has not always been recorded advantageous in discriminating LAB strains. For example, in a previous study, it was found that PFGE showed higher resolving power than MLST in discriminating the $L b$. casei strains. MLST differentiated 36 out of $40 \mathrm{Lb}$. casei strains, while PFGE differentiated all the 40 strains (Cai et al., 2007). Likewise, in a recent study, AFLP was found to be more efficient than MLST in differentiating the Oenococcusoeni strains (Yu et al., 2018).

MLST has a high discriminatory power, and it provides explicit results that can be compared to those obtained in different laboratories. Nevertheless, it has practical disadvantages, including high cost and restricted accessibility (Sullivan et al., 2006). Furthermore, since housekeeping genes are conserved in nature and highly variable in different bacterial species, MLST may not adequately discriminate unrelated isolates.

\section{Real-time PCR}

The most important breakthrough in the application of PCR was observing DNA amplification based on the fluorescence emission in real-time (Holland et al., 1991). Realtime PCR can be used based on the goal of the study: absolute (standard curve) or relative (comparative threshold method) quantification(Arya et al., 2005). Absolute quantification depends on the preparation of a standard curve using diluted template samples of known 
Fig. 5 Schematic diagram for real-time PCR $(\mathbf{A})$ and microarrays $(\mathbf{B})$

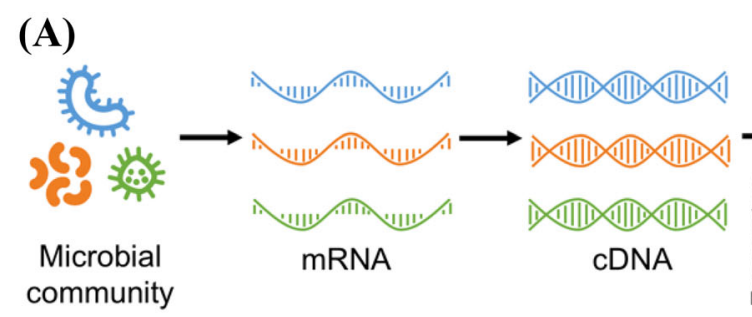

(B)

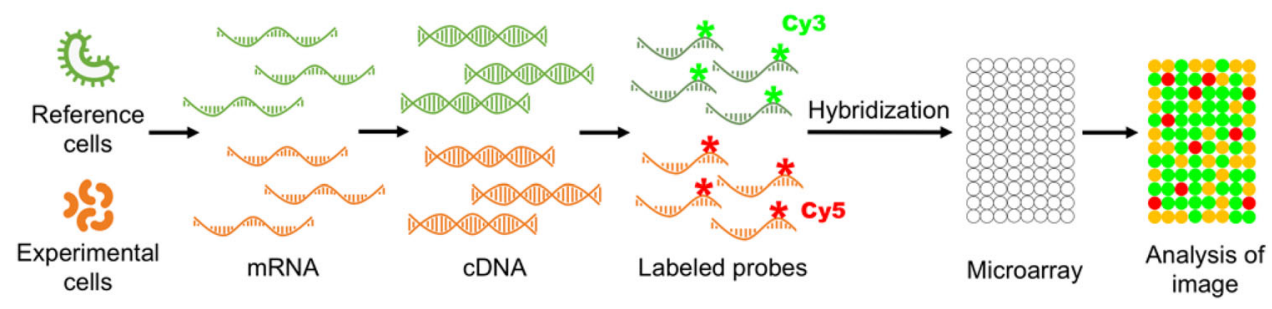

concentrations, including a plasmid containing the cloned gene of interest, a synthetic oligonucleotide (single sense), genomic DNA, cDNA, total RNA, or in vitro transcripts (Arya et al., 2005). The standard curve approach is used to quantify viral load or the exact level of the DNA template in the samples (Kralik and Ricchi 2017). Relative quantification is based on mathematical calculations that are used to quantify the relative expression of a target compared to that of a control (Arya et al., 2005). It is used to analyze the gene expression and comparative amount of DNA (Fig. 5(A)).

Real-time PCR is a DNA-based technique that has been widely used to quantify LAB species from various samples, including food, milk, and feces. It is based on the principle of measuring the intensity of the fluorescence of the product generated during each amplification cycle of the PCR process, and this intensity is directly proportional to the increase in the amount of the amplicon at that specific time (Kralik and Ricchi 2017). Fluorescent-labeled oligonucleotide probes [hydrolysis probes (TaqMan ${ }^{\circledR}$ assay), Molecular Beacons and Scorpions] and non-sequencespecific double standard DNA fluorescent intercalating dyes (SYBR Green I) (Mackay et al., 2002) are the two most widely used methods to monitor the real-time target sequence amplification. Several different PCR instruments and probe formats are available for real-time detection. The probe-based approach shows promise owing to the lesser chance of developing non-specific PCR products (primerdimers) and higher specificity facilitated by the extra oligonucleotide (Hein et al., 2001; Kubista et al., 2006). However, SYBR Green I dye can be used to identify a target from a mixed population using PCR. In addition, real-time PCR enables precise quantification of templates of more than $10^{7}$-fold dynamic range (Stefanis et al., 2016).
The principle benefit of this method is that it is sensitive and suitable to quantify LAB. It is a superior tool compared to conventional PCR-based techniques because it circumvents the necessity for post-PCR handling. In addition, no tiresome selective bacterial culturing is required, as demanded by other genotypic methods (Sattler et al., 2014). Furthermore, the performance of real-time PCR can be significantly improved in a multiplex setup, in which more sequences are simultaneously targeted (Bottari et al., 2013). This can be conducted using the new closed-tube structures that decrease the possibility of contamination during real-time PCR. The biggest disadvantage, however, is the failure to differentiate dead bacteria from the living. This can occur because DNA can be amplified from dead cells too (Josephson et al., 1993; Justé et al., 2008; Kralik and Ricchi 2017). Another limitation is that in the reaction tube, the target DNA amplicons are restricted due to the different natures of the illuminating light sources and fewer fluorescent dyes (Mackay et al., 2002). A modification of this method, multiplex real-time PCR, permits the amplification of more than one target in a single reaction using distinct reporters with different fluorescent spectra.

A previous study used real-time PCR to enumerate $L b$. lactis subsp. cremoris, Lb. lactis subsp. lactis, and the Leu. sp. relatively for the first time, and these results were compared to those obtained by flow cytometry-fluorescence in situ hybridization (FLOW-FISH). On comparison, we found that quantitative PCR was more flexible than FLOW-FISH (Friedrich and Lenke 2006). Bottari et al. documented a multiplex real-time PCR system used to directly identify the thermophilic LAB, including $\mathrm{Lb}$. delbrueckii, Lb. helveticus, St. thermophilus, and Lb. fermentum in undefined starter cultures of hard cooked cheeses (Bottari et al., 2013). This tool was found to be 
more effective and faster than the length-heterogeneity PCR and FISH methods (Bottari et al., 2013). Furet et al. used real-time PCR for the specific detection and quantification of Lb. acidophilus, Lb. delbrueckii, St. thermophilus, Lb. johnsonii, Lb. rhamnosus, and Lb. paracasei in commercial fermented milk products (Furet et al., 2004). Recently, real-time PCR has been used for the quantification of thermophilic Lb. delbrueckii subsp. bulgaricus and St. thermophilus, which are commonly used for milk fermentation and cheese ripening (Stachelska and Foligni 2018). Another study described the use of strain-specific real-time PCR for enumerating the Lb. reuteri strains in a chicken feed (from three separate locations) in the three sections (ileum, jejunum, and caecum) of the gastrointestinal tract of birds of different ages (Sattler et al., 2014). Pontonio et al. used real-time PCR for the differentiation of LAB in bread that was made with or without sourdough (Pontonio et al., 2017). In a recent study in China, real-time PCR was utilized to assess the LAB biodiversity in 86 fermented milk products. Among the $705 \mathrm{LAB}$ species that were identified, Lb. delbrueckii subsp. bulgaricus, Lb. helveticus, and $L b$. fermentum were the major species. Significantly different microbiota were found in cow and yak milk samples (Mo et al., 2019).

\section{Microarrays}

Microarray is a novel genomic tool widely used to investigate transcriptional profiles across genomes (Rick et al., 2001). Generally, the types of microarrays include cDNA microarrays, oligonucleotide microarrays, and serial analysis of gene expression. Microarrays work on the principle that complementary sequences bind to each other. Briefly, a DNA microarray experiment consists of array fabrication, probe preparation, hybridization, and data analysis. The labeled [usually with red (Cy5) and green (Cy3) dyes] cDNA interacts with a particular immobilized probe. The signal generated from this interaction provides information on the type of RNA present in the undetermined target specimen (Fig. 5(B)). In simple terms, microarray provides diagnostic data, which is information on the gene expression. Hence, microarray can be applied to analyze the gene expression profiles across genomes and similarity or dissimilarity of the genome levels of diverse microorganisms. Microarrays can be differentiated based on their features, including surface support, probe type, and approach to recognize the target (Miller 2011).

The genomic data have been used to design numerous species-specific microarrays that permit the monitoring of the expression of all genes of a single LAB species and observation of the remarkable metabolic functions during monoculture experiments (Kuipers et al., 2002; Pieterse et al., 2005). Furthermore, Weckx et al. identified and validated a species-independent microarray of 406 functional genes that targeted $\mathrm{LAB}$ to evaluate the gene expression levels. The study demonstrated the use of genespecific oligonucleotide design algorithm to hybridize multiple species of LAB (Weckx et al., 2009). Another study described the anti-colitic effect of a mixture of LAB strains, including Bif. longum, Lb. brevis, and Lb. suntoryeus, in a colitic ICR mouse (induced by dextran sulfate) using cDNA microarray and qPCR. The results showed that the supplemented mixture ameliorated colitis by reducing the expression levels of tumor necrosis factor (TNF)- $\alpha$, interleukin (IL)-1 $\beta$, and cyclo-oxygenase (COX)2 (Lee et al., 2009). The reformed functional potential of a mutated Lac. lactis strain was analyzed based on its genetic and microarray information (Chen et al., 2015). While microarrays are still considered important and cost-effective techniques for the analysis of different microbial communities, the next-generation sequencing (NGS) tools are supplanting them with each passing year (Ledford 2008).

\section{Mass spectrometry (MS)}

For bacterial typing, there are three basic platforms of MS, including matrix-assisted laser desorption/ionization-time of flight (MALDI-TOF) MS, liquid chromatography (LC)MS/MS, and targeted LC-MS/MS (Cheng et al., 2016; Ferranti 2004; Vinusha et al., 2018). In MALDI-TOF, the target bacteria are treated with laser radiations, which are transferred through the matrix. Different ions that are generated move towards a detector at varying speeds. The obtained fingerprints are compared for the identification and characterization of bacterial strains. The use of MALDI-TOF MS is advantageous in the analysis of proteins of large sizes. The LC-MS/MS approach to fingerprinting is based on peptide analysis. For peptide generation, proteins from the target bacteria are concentrated, converted into peptides using enzymes (e.g., trypsin), separated using LC, ionized using electrospray ionization (ESI), and analyzed using MS. The ionized peptides are additionally fragmented, and the obtained sequences are used for identifying the bacteria (Vinusha et al., 2018) (Fig. 6(A)). Targeted LC-MS/MS uses standards labeled with stable isotopes for the identification and quantification of the target peptide. The applications of the MS tool include obtaining information on the peptide mass, new amino acid sequence data, and information on posttranslational modifications in proteins (Table 1).

The advantages of the MS technology are that it is consistent, robust, and cheap, requires only a small amount of the sample, consumes less time, and manages data 
Fig. 6 Schematic diagram for mass spectrometry (A) and whole-genome sequencing (B)
(A)

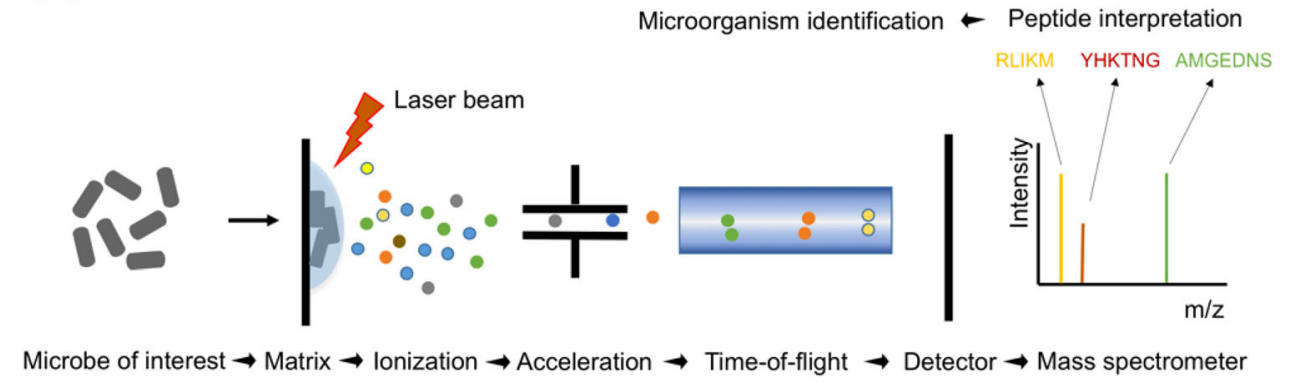

(B)

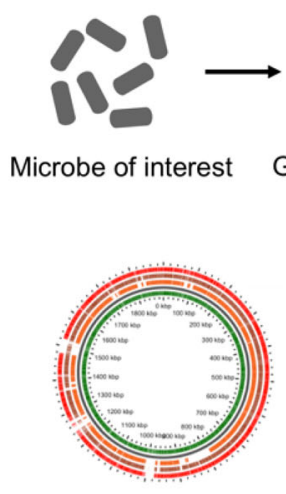

better. The disadvantages include database dependency, requirement of trained staff, and inability in identifying non-viable microbes.

The technique MALDI-TOF MS has been applied to identify LAB from French Maroilles cheese. MALDI-TOF MS identified 105 and 92 LAB strains from Maroilles cheese synthesized using raw milk and pasteurized milk, respectively. Among the three identified genera, namely Lactobacillus, Leuconostoc, and Enterococcus, Lactobacillus was the most prominent genus with the Lb. brevis, $L b$. plantarum, Lb. curvatus (recently reclassified as Latilactobacillus curvatus, Zheng et al., 2020), Lb. paracasei, Lb. rhamnosus, Lb. parabuchneri, and Lb. fructivorans species (Nacef et al., 2017). Likewise, this tool was applied to identify LAB species from two fishes, namely Oreochromis niloticus and Mugil cephalis. The identified genera included Leuconostoc, Enterococcus, Lactococcus, and Vagococcus (El-Jeni et al., 2019). Another recent study used MALDI-TOF MS to identify nonstarter LAB isolates from four artisanal kinds of cheeses, namely Kefalotyri, Anthotyro, Xynotyri, and Touloumotyri, synthesized from raw goat and sheep milk. The identified LAB species included Lb. brevis, Lb. rhamnosus, Lb. plantarum, Lb. paracasei, Leu. mesenteroides, Enterococcus faecium, Lac. lactis, and P. pentosaceus (Gantzias et al., 2020). Albesharat et al. assessed the LAB strains in breast milk, feces of mothers and babies, and local foods (fermented) using genotypic tools such as MALDI-TOF MS, 16S RNA gene sequencing, and RAPD (Albesharat et al., 2011). They identified the Lactobacillus, Streptococcus, Pediococcus, Enterococcus, and Weissella genera. Specifically, Lb. brevis, Lb. fermentum, Lb. plantarum, and P. pentosaceus were identified in all the sources (Albesharat et al., 2011).

In a recent study, MALDI-TOF MS and 16S rRNA gene sequencing were used to identify LAB species from byproducts of fruits (mango, strawberry, Barbados cherry, and soursop). The identification match for both techniques was $86 \%$. The predominant genus was Lactobacillus, which included the $L b$. brevis, Lb. fermentum, Lb. pentosus, Lb. paracasei, Lb. plantarum, Lb. casei, and Lb. nagelii (recently reclassified as Liquorilactobacillus nagelii, Zheng et al., 2020) (Garcia et al., 2016). Russo et al. applied the nano-LC-ESI-MS/MS tool to identify LAB in whey starter cultures by utilizing species-specific peptide markers at the genus, species, and subspecies levels for the first time (Russo et al., 2019).

\section{Whole-genome sequencing (WGS)}

The introduction and availability of NGS and 3rd generation technology, including WGS and high-throughput sequencing, has resulted in an unprecedented rise in the volume of sequencing-based data (Kwong et al., 2015). 


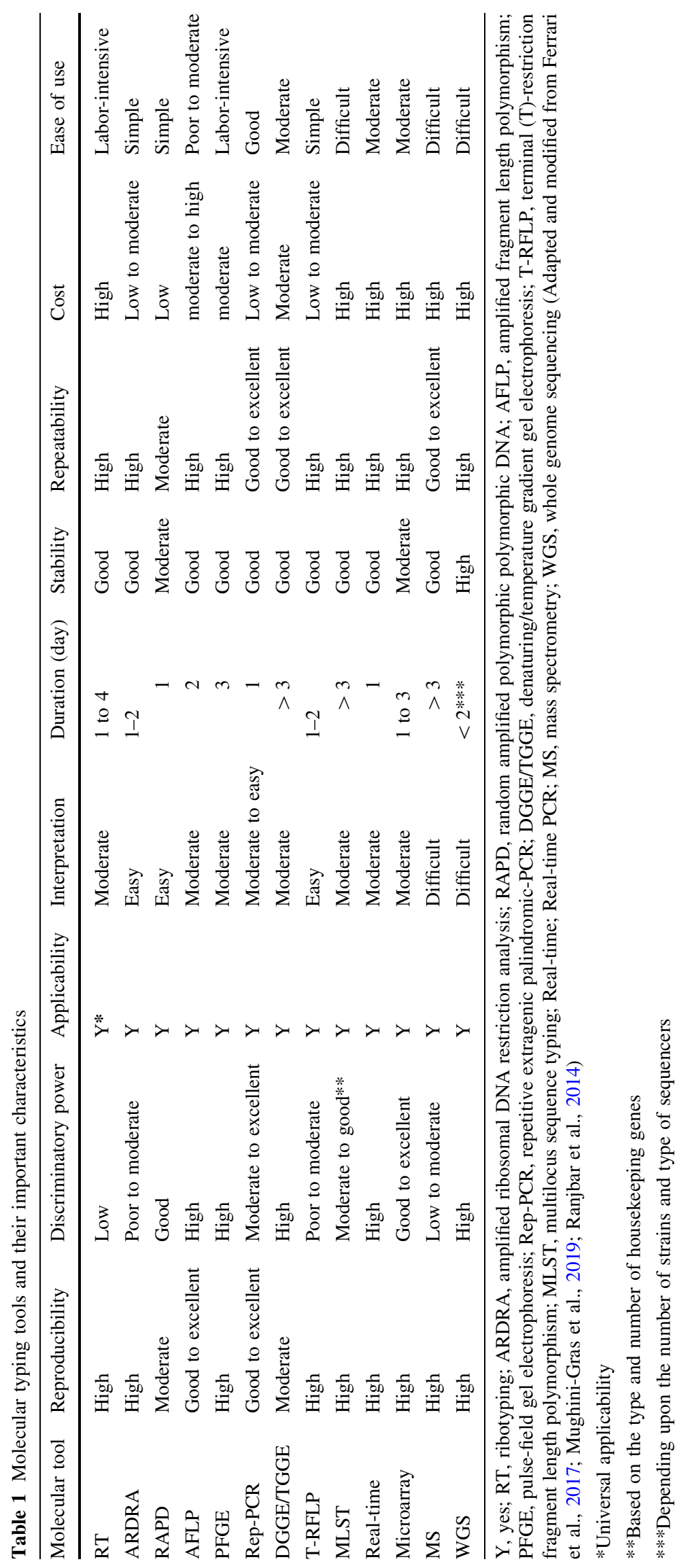


The sequencing of the complete genome sequences of diverse LAB strains enables introduction of new approaches that can be used to deduce the evolutionary and divergence relationships among the strains (Coenye and Vandamme 2003). WGS is a powerful approach used to characterize strains accurately and interpret functions of LAB at the genome level (Buron-Moles et al., 2019). Furthermore, WGS may provide information on the antimicrobial resistance of the LAB strains. The first LAB genome was released in 2001 (Bolotin et al., 2001). Subsequently, full genome sequences of many other LAB species have been made readily accessible (Chenoll et al., 2015; Inglin et al., 2018; Sun et al., 2015; Wu et al., 2017; Zheng et al., 2015).

WGS technology is gradually substituting customary microbial typing and characterization methods and offering faster and more accurate answers (Jagadeesan et al., 2019). WGS is gaining attention as a potential approach for the surveillance of food-borne illnesses (Allard et al., 2016; Ashton et al., 2016). Currently, there are two methods that can be used to analyze WGS data to determine the similarities among the strains: single nucleotide polymorphism (SNP)- and gene by gene-based approaches. Investigation of WGS data through either method is a dynamic process, which involves several steps to generate outcomes, such as allele matrices and phylogenetic relationships (Fig. 6(B)).

In the SNP-based method, the target genome is compared with the reference genome to obtain information on the nucleotide differences. On the other hand, the gene by gene-based method, an alternate approach to traditional MLST, is classified into whole genome (wg) MLST and core genome (cg) MLST, and can be used to analyze the genetic relatedness among the LAB strains (Schürch et al., 2018). In this approach, compared to the conventional MLST method, alleles are assigned using big data pools that are generated through multiple comparisons between genomes or several genes and the curated genomic information to corroborate reproducibility among the results obtained by different laboratories. A recent cg study assessed $56 \mathrm{LAB}$ genomes to trace the genetic determinants of the carbohydrate metabolism in the strains. The study found that 219 single-copy genes were shared among these 56 strains (Buron-Moles et al., 2019). Kant et al. reported 383 core gene sets by comparing 20 Lactobacillus genomes (Kant et al., 2011). The genome data offered a greater resolution than that obtained using the other previously described genotyping tools. However, there are some blockades to the extensive employment of WGS in different laboratories. This method requires expensive equipment and a bioinformatician to handle the technical data. Furthermore, while many WGS analyses can be theoretically conducted on standard computers, the computational power required for processing and analyzing large numbers of genomes is important (Kwong et al., 2015).

Probiotics have developed into a significant health concern worldwide. As previously described, several typing tools have been established to identify and classify probiotics or LAB strains and find a genetic link among these beneficial microbes. The conventional phenotypic approaches have merits and pitfalls that affect their utility. Though the use of a wide range of molecular techniques has facilitated the typing of LAB strains, a polyphasic approach that consists of two or more typing tools is ideal for the correct documentation of LAB strains. Furthermore, development and access to the NGS techniques, including WGS, has allowed for the analysis of the differences in DNA sequences. It can be anticipated that in the near future, these technologies will replace traditional typing tools. However, these sequencing-based techniques are available only in well-equipped laboratories and require highly qualified personnel. In our opinion, for the analysis of a limited number of strains, less innovative methods will still be used, and hence, the development of easy, quick, and cost-effective techniques with high discriminatory power is necessary.

Acknowledgments This work was supported by the National Research Foundation of Korea (NRF) grant funded by the Korea government (MSIT) (No. 2019R1A2C1004950).

\section{Compliance with ethical standards}

Conflict of interest The authors declare no conflict of interest.

Open Access This article is licensed under a Creative Commons Attribution 4.0 International License, which permits use, sharing, adaptation, distribution and reproduction in any medium or format, as long as you give appropriate credit to the original author(s) and the source, provide a link to the Creative Commons licence, and indicate if changes were made. The images or other third party material in this article are included in the article's Creative Commons licence, unless indicated otherwise in a credit line to the material. If material is not included in the article's Creative Commons licence and your intended use is not permitted by statutory regulation or exceeds the permitted use, you will need to obtain permission directly from the copyright holder. To view a copy of this licence, visit http://creativecommons. org/licenses/by/4.0/.

\section{References}

Albesharat R, Ehrmann MA, Korakli M, Yazaji S, Vogel RF. Phenotypic and genotypic analyses of lactic acid bacteria in local fermented food, breast milk and faeces of mothers and their babies. Syst. Appl. Microbiol. 34: 148-155 (2011)

Allard MW, Strain E, Melka D, Bunning K, Musser SM, Brown EW, Timme R. Practical value of food pathogen traceability through building a whole-genome sequencing network and database. J. Clin. Microbiol. 54: 1975-1983 (2016) 
Arya M, Shergill IS, Williamson M, Gommersall L, Arya N, Patel HR. Basic principles of real-time quantitative PCR. Expert Rev. Mol. Diagn. 5: 209-219 (2005)

Ashton PM, Nair S, Peters TM, Bale JA, Powell DG, Painset A, Tewolde R, Schaefer U, Jenkins C, Dallman TJ. Identification of Salmonella for public health surveillance using whole genome sequencing. PeerJ 4: e1752 (2016)

Baniyah L, Jannah SN, Rukmi I. Molecular diversity of lactic acid bacteria on ileum broiler chicken fed by bran and bran fermentation. J. Phys. Conf. Ser. 1025: 012049 (2018)

Bao Q, Song Y, Xu H, Yu J, Zhang W, Menghe B, Zhang H, Sun Z. Multilocus sequence typing of Lactobacillus casei isolates from naturally fermented foods in China and Mongolia. J. Dairy Sci. 99: 5202-5213 (2016)

Ben Amor K, Vaughan EE, de Vos WM. Advanced molecular tools for the identification of lactic acid bacteria. J. Nutr. 137: 741-747 (2007)

Bokulich NA, Mills DA. Differentiation of mixed lactic acid bacteria communities in beverage fermentations using targeted terminal restriction fragment length polymorphism. Food Microbiol. 31: 126-132 (2012)

Bolotin A, Wincker P, Mauger S, Jaillon O, Malarme K, Weissenbach J, Ehrlich SD, Sorokin A. The complete genome sequence of the lactic acid bacterium Lactococcus lactis ssp. lactis IL1403. Genome Res. 11: 731-753 (2001)

Bottari B, Agrimonti C, Gatti M, Neviani E, Marmiroli N. Development of a multiplex real time PCR to detect thermophilic lactic acid bacteria in natural whey starters. Int. J. Food Microbiol. 160: 290-297 (2013)

Bove C, Lazzi C, Bernini V, Bottari B, Neviani E, Gatti M. cDNAamplified fragment length polymorphism to study the transcriptional responses of Lactobacillus rhamnosus growing in cheeselike medium. J. Appl. Microbiol. 111: 855-864 (2011)

Buron-Moles G, Chailyan A, Dolejs I, Forster J, Mikš MH. Uncovering carbohydrate metabolism through a genotype-phenotype association study of 56 lactic acid bacteria genomes. Appl. Microbiol. Biotechnol. 103: 3135-3152 (2019)

Cai H, Rodríguez BT, Zhang W, Broadbent JR, Steele JL. Genotypic and phenotypic characterization of Lactobacillus casei strains isolated from different ecological niches suggests frequent recombination and niche specificity. Microbiology 153: 2655-2665 (2007)

Ceapa C, Lambert J, van Limpt K, Wels M, Smokvina T, Knol J, Kleerebezem M. Correlation of Lactobacillus rhamnosus genotypes and carbohydrate utilization signatures determined by phenotype profiling. Appl. Environ. Microbiol. 81: 5458-5470 (2015)

Chen BY, Pyla R, Kim TJ, Silva JL, Jung YS. Prevalence and contamination patterns of Listeria monocytogenes in catfish processing environment and fresh fillets. Food Microbiol. 27: 645-652 (2010)

Chen J, Shen J, Hellgren LI, Jensen PR, Solem C. Adaptation of Lactococcus lactis to high growth temperature leads to a dramatic increase in acidification rate. Sci. Rep. 5: 14199 (2015)

Chen W, Gu Z. Genomic analysis of lactic acid bacteria and their applications. pp 21-49. In:Lactic Acid Bacteria in Foodborne Hazards Reduction, 1 edn. Springer, Singapore (2018)

Cheng K, Chui H, Domish L, Hernandez D, Wang G. Recent development of mass spectrometry and proteomics applications in identification and typing of bacteria. Proteom. Clin. Appl. 10: 346-357 (2016)

Chenoll E, Rivero M, Codoñer FM, Martinez-Blanch JF, Ramón D, Genovés S, Muñoz JAM. Complete genome sequence of Bifidobacterium longum subsp. infantis strain CECT 7210, a probiotic strain active against rotavirus infections. Genome Announc. 3: e00105-e00115 (2015)
Coenye T, Vandamme P. Extracting phylogenetic information from whole-genome sequencing projects: the lactic acid bacteria as a test case. Microbiology 149: 3507-3517 (2003)

De Las Rivas B, Marcobal A, Munoz R. Allelic diversity and population structure in Oenococcus oeni as determined from sequence analysis of housekeeping genes. Appl. Environ. Microbiol. 70: 7210-7219 (2004)

de las Rivas B, Marcobal Á, Munoz R. Development of a multilocus sequence typing method for analysis of Lactobacillus plantarum strains. Microbiology 152: 85-93 (2006)

Delorme C, Legravet N, Jamet E, Hoarau C, Alexandre B, El-Sharoud WM, Darwish MS, Renault P. Study of Streptococcus thermophilus population on a world-wide and historical collection by a new MLST scheme. Int. J. Food Microbiol. 242: 70-81 (2017)

Diancourt L, Passet V, Chervaux C, Garault P, Smokvina T, Brisse S. Multilocus sequence typing of Lactobacillus casei reveals a clonal population structure with low levels of homologous recombination. Appl. Environ. Microbiol. 73: 6601-6611 (2007)

Dimitrov Z. Assessment of Lactobacillus bulgaricus strain in human intestinal samples by denaturation gradient gel electrophoresis. TJS 17: 312-317 (2019)

El-Jeni R, Böhme K, El Bour M, Calo-Mata P, Kefi R, BarrosVelázquez J, Bouhaouala-Zahar B. Rapid genus identification of selected lactic acid bacteria isolated from Mugil cephalis and Oreochromis niloticus organs using MALDI-TOF. Ann. Microbiol. 69: 1-15 (2019)

FAO/WHO. Guidelines for the Evaluation of Probiotics in Food. FAO/WHO, London, ON, CA (2002)

Feng J, Jiang Y, Li M, Zhao S, Zhang Y, Li X, Wang H, Lin G, Wang $\mathrm{H}, \mathrm{Li}$ T. Diversity and evolution of Lactobacillus casei group isolated from fermented dairy products in Tibet. Arch. Microbiol. 200: 1111-1121 (2018)

Ferranti P. Mass spectrometric approach for the analysis of food proteins. Eur. J. Mass Spectrom. 10: 349-358 (2004)

Ferrari RG, Panzenhagen PHN, Conte-Junior CA. Phenotypic and genotypic eligible methods for Salmonella Typhimurium source tracking. Front. Microbiol. 8: 2587 (2017)

Friedrich U, Lenke J. Improved enumeration of lactic acid bacteria in mesophilic dairy starter cultures by using multiplex quantitative real-time PCR and flow cytometry-fluorescence in situ hybridization. Appl. Environ. Microbiol. 72: 4163-4171 (2006)

Fu LL, Li JR. Microbial source tracking: a tool for identifying sources of microbial contamination in the food chain. Crit. Rev. Food Sci. Nutr. 54: 699-707 (2014)

Furet JP, Quénée P, Tailliez P. Molecular quantification of lactic acid bacteria in fermented milk products using real-time quantitative PCR. Int. J. Food Microbiol. 97: 197-207 (2004)

Fusco V, Quero GM, Chieffi D, Franz CM. Identification of Lactobacillus brevis using a species-specific AFLP-derived marker. Int. J. Food Microbiol. 232: 90-94 (2016)

Galanis A, Kourkoutas Y, Tassou CC, Chorianopoulos N. Detection and identification of probiotic Lactobacillus plantarum strains by multiplex PCR using RAPD-derived primers. Int. J. Mol. Sci. 16: 25141-25153 (2015)

Gantzias C, Lappa IK, Aerts M, Georgalaki M, Manolopoulou E, Papadimitriou K, De Brandt E, Tsakalidou E, Vandamme P. MALDI-TOF MS profiling of non-starter lactic acid bacteria from artisanal cheeses of the Greek island of Naxos. Int. J. Food Microbiol. 323: 108586 (2020)

Garcia EF, Luciano WA, Xavier DE, da Costa WC, de Sousa Oliveira K, Franco OL, de Morais Júnior MA, Lucena BT, Picão RC, Magnani M. Identification of lactic acid bacteria in fruit pulp processing byproducts and potential probiotic properties of selected Lactobacillus strains. Front. Microbiol. 7: 1371 (2016) 
Gevers D, Huys G, Swings J. Applicability of rep-PCR fingerprinting for identification of Lactobacillus species. FEMS Microbiol. Lett. 205: 31-36 (2001)

Giammanco GM, Mammina C, Romani C, Luzzi I, Dionisi AM, Nastasi A. Evaluation of a modified single-enzyme amplified fragment length polymorphism (SE-AFLP) technique for subtyping Salmonella enterica serotype Enteritidis. Res. Microbiol. 158: 10-17 (2007)

Giraffa G, Gatti M, Rossetti L, Senini L, Neviani E. Molecular diversity within Lactobacillus helveticus as revealed by genotypic characterization. Appl. Environ. Microbiol. 66: 1259-1265 (2000)

Giraffa G, Neviani E. Molecular identification and characterization of food-associated lactobacilli. Ital. J. Food Sci. 12: 403-423 (2000)

Guarcello R, De Angelis M, Settanni L, Formiglio S, Gaglio R, Minervini F, Moschetti G, Gobbetti M. Selection of amineoxidizing dairy lactic acid bacteria and identification of the enzyme and gene involved in the decrease of biogenic amines. Appl. Environ. Microbiol. 82: 6870-6880 (2016)

Hagen KE, Tannock GW, Korver DR, Fasenko GM, Allison GE. Detection and identification of Lactobacillus species in crops of broilers of different ages by using PCR-denaturing gradient gel electrophoresis and amplified ribosomal DNA restriction analysis. Appl. Environ. Microbiol. 69: 6750-6757 (2003)

Hein I, Lehner A, Rieck P, Klein K, Brandl E, Wagner M. Comparison of different approaches to quantify Staphylococcus aureus cells by real-time quantitative PCR and application of this technique for examination of cheese. Appl. Environ. Microbiol. 67: 3122-3126 (2001)

Holland PM, Abramson RD, Watson R, Gelfand DH. Detection of specific polymerase chain reaction product by utilizing the $5^{\prime}-$ $3^{\prime}$ exonuclease activity of Thermus aquaticus DNA polymerase. Proc. Nat. Acad. Sci. 88: 7276-7280 (1991)

Holzapfel WH, Haberer P, Geisen R, Björkroth J, Schillinger U. Taxonomy and important features of probiotic microorganisms in food and nutrition. Am. J. Clin. Nutr. 73: 365-373 (2001)

Hong SW, Choi YJ, Lee HW, Yang JH, Lee MA. Microbial community structure of Korean cabbage kimchi and ingredients with denaturing gradient gel electrophoresis. J. Microbiol. Biotechnol. 26: 1057-1062 (2016)

Inglin RC, Meile L, Stevens MJ. Clustering of pan-and core-genome of Lactobacillus provides novel evolutionary insights for differentiation. BMC Genom. 19: 284 (2018)

Jagadeesan B, Gerner-Smidt P, Allard MW, Leuillet S, Winkler A, Xiao Y, Chaffron S, Van Der Vossen J, Tang S, Katase M. The use of next generation sequencing for improving food safety: translation into practice. Food Microbiol. 79: 96-115 (2019)

Jarocki P, Podleśny M, Komoń-Janczara E, Kucharska J, Glibowska A, Targoński Z. Comparison of various molecular methods for rapid differentiation of intestinal bifidobacteria at the species, subspecies and strain level. BMC Microbiol. 16: 159 (2016)

Josephson K, Gerba CP, Pepper IL. Polymerase chain reaction detection of nonviable bacterial pathogens. Appl. Environ. Microbiol. 59: 3513-3515 (1993)

Justé A, Thomma B, Lievens B. Recent advances in molecular techniques to study microbial communities in food-associated matrices and processes. Food Microbiol. 25: 745-761 (2008)

Kakelar HM, Barzegari A, Hanifian S, Barar J, Omidi Y. Isolation and molecular identification of Lactobacillus with probiotic potential from abomasums driven rennet. Food Chem. 272: 709-714 (2019)

Kant R, Blom J, Palva A, Siezen RJ, de Vos WM. Comparative genomics of Lactobacillus. Microbial Biotechnol. 4: 323-332 (2011)

Kaur J, Lee S, Park YS, Sharma A. RAPD analysis of Leuconostoc mesenteroides strains associated with vegetables and food products from Korea. LWT-Food Sci. Technol. 77: 383-388 (2017a)

Kaur J, Lee S, Sharma A, Park YS. DNA profiling of Leuconostoc mesenteroides strains isolated from fermented foods and farm produce in Korea by repetitive-element PCR. Food Sci. Biotechnol. 26: 1667-1673 (2017b)

Kaur J, Sharma A, Lee S, Park YS. DNA profiling of Leuconostoc citreum strains in fermented foods by repetitive element polymerase chain reaction. J. Microbiol. Biotechnol. 27: $1778-1782(2017 \mathrm{c})$

Kaur J, Sharma A, Lee S, Park YS. Molecular typing of Lactobacillus brevis isolates from Korean food using repetitive elementpolymerase chain reaction. Food Sci. Tech. Int. 24: 341-350 (2018)

Klein G, Pack A, Bonaparte C, Reuter G. Taxonomy and physiology of probiotic lactic acid bacteria. Int. J. Food Microbiol. 41: 103-125 (1998)

Kralik P, Ricchi M. A basic guide to real time PCR in microbial diagnostics: definitions, parameters, and everything. Front. Microbiol. 8: 108 (2017)

Kubista M, Andrade JM, Bengtsson M, Forootan A, Jonák J, Lind K, Sindelka R, Sjöback R, Sjögreen B, Strömbom L. The real-time polymerase chain reaction. Mol. Aspects Med. 27: 95-125 (2006)

Kuipers OP, de Jong A, Baerends RJ, van Hijum SA, Zomer AL, Karsens HA, Den Hengst CD, Kramer NE, Buist G, Kok J. Transcriptome analysis and related databases of Lactococcus lactis. Anton. Leeuw. Int. J. G. 82: 113-122 (2002)

Kwong JC, McCallum N, Sintchenko V, Howden BP. Whole genome sequencing in clinical and public health microbiology. Pathology 47: 199-210 (2015)

Ledford H. The death of microarrays? Nature 455: 847 (2008)

Lee CM, Sieo CC, Cheah YK, Abdullah N, Ho YW. Discrimination of probiotic Lactobacillus strains for poultry by repetitive sequenced-based PCR fingerprinting. J. Sci. Food Agr. 92: 660-666 (2012)

Lee H, Ahn YT, Lee JH, Huh CS, Kim DH. Evaluation of anti-colitic effect of lactic acid bacteria in mice by cDNA microarray analysis. Inflammation 32: 379-386 (2009)

Liang H, Chen H, Ji C, Lin X, Zhang W, Li L. Dynamic and functional characteristics of predominant species in industrial paocai as revealed by combined DGGE and metagenomic sequencing. Front. Microbiol. 9: 2416 (2018)

Mackay IM, Arden KE, Nitsche A. Real-time PCR in virology. Nucleic Acids Res. 30: 1292-1305 (2002)

Maiden MC, Van Rensburg MJJ, Bray JE, Earle SG, Ford SA, Jolley KA, McCarthy ND. MLST revisited: the gene-by-gene approach to bacterial genomics. Nat. Rev. Microbiol. 11: 728-736 (2013)

Manan N, Chin S, Abdullah N, Wan H. Differentiation of Lactobacillus-probiotic strains by visual comparison of random amplified polymorphic DNA (RAPD) profiles. African J. Biotechnol. 8: 3964-3969 (2009)

Masco L, Huys G, Gevers D, Verbrugghen L, Swings J. Identification of Bifidobacterium species using rep-PCR fingerprinting. Syst. Appl. Microbiol. 26: 557-563 (2003)

Miller MB. Solid- and liquid- phase array technologies. pp. 275-297. In: Molecular Microbiology. Persing D, Tenover F, Tang Y, Nolte F, Hayden R, van Belkum A (eds). ASM Press, WA, USA (2011)

Mo L, Jin H, Pan L, Hou Q, Li C, Darima I, Zhang H, Yu J. Biodiversity of lactic acid bacteria isolated from fermented milk products in Xinjiang, China. Food Biotechnol. 33: 174-192 (2019)

Mohkam M, Nezafat N, Berenjian A, Mobasher MA, Ghasemi Y. Identification of Bacillus probiotics isolated from soil 
rhizosphere using 16S rRNA, recA, rpoB gene sequencing and RAPD-PCR. Probiotics Antimicrob. Proteins 8: 8-18 (2016)

Mughini-Gras L, Kooh P, Fravalo P, Augustin J-C, Guillier L, David J, Thêbault A, Carlin F, Leclercq A, Jourdan-Da-Silva N, Pavio N, Villena I, Sanaa M, Watier L. Critical orientation in the jungle of currently available methods and types of data for source attribution of foodborne diseases. Front. Microbiol. 10: 2578 (2019)

Muyzer G. DGGE/TGGE a method for identifying genes from natural ecosystems. Curr. Opin. Microbiol. 2: 317-322 (1999)

Muyzer G, Smalla K. Application of denaturing gradient gel electrophoresis (DGGE) and temperature gradient gel electrophoresis (TGGE) in microbial ecology. Anton. Leeuw. Int. J. G. 73: 127-141 (1998)

Nacef M, Chevalier M, Chollet S, Drider D, Flahaut C. MALDI-TOF mass spectrometry for the identification of lactic acid bacteria isolated from a French cheese: The Maroilles. Int. J. Food Micobiol. 247: 2-8 (2017)

Neoh HM, Tan XE, Sapri HF, Tan TL. Pulsed-field gel electrophoresis (PFGE): A review of the "gold standard" for bacteria typing and current alternatives. Infect. Genet. Evol. 74: 103935 (2019)

Ngoi ST, Teh CSJ, Chai LC, Thong KL. Overview of molecular typing tools for the characterization of Salmonella enterica in Malaysia. Biomed. Environ. Sci. 28: 751-764 (2015)

Nishino N, Ogata Y, Han H, Yamamoto Y. Identification of bacteria in total mixed ration silage produced with and without crop silage as an ingredient. Animal Sci. J. 86: 45-50 (2015)

Østlie HM, Eliassen L, Florvaag A, Skeie S. Phenotypic and PCRbased characterization of the microflora in Norvegia cheese during ripening. Int. J. Food Microbiol. 94: 287-299 (2004)

Öztürk M, Meterelliyöz M. Practical identification of human originated Lactobacillus species by amplified ribosomal DNA restriction analysis (ARDRA) for probiotic use. Mol. Biol. Rep. 42: 1323-1332 (2015)

Pieterse B, Leer RJ, Schuren FH, van der Werf MJ. Unravelling the multiple effects of lactic acid stress on Lactobacillus plantarum by transcription profiling. Microbiology 151: 3881-3894 (2005)

Plessas S, Nouska C, Karapetsas A, Kazakos S, Alexopoulos A, Mantzourani I, Chondrou P, Fournomiti M, Galanis A, Bezirtzoglou E. Isolation, characterization and evaluation of the probiotic potential of a novel Lactobacillus strain isolated from Feta-type cheese. Food Chem. 226: 102-108 (2017)

Pogačić T, Kelava N, Zamberlin Š, Dolenčić-Špehar I, Samaržija D. Methods for culture-independent identification of lactic acid bacteria in dairy products. Food Technol. Biotechnol. 48: 3-10 (2010)

Pontonio E, Di Cagno R, Mahony J, Lanera A, De Angelis M, van Sinderen D, Gobbetti M. Sourdough authentication: quantitative PCR to detect the lactic acid bacterial microbiota in breads. Sci. Rep. 7: 1-13 (2017)

Ranjbar R, Karami A, Farshad S, Giammanco GM, Mammina C. Typing methods used in the molecular epidemiology of microbial pathogens: a how-to guide. New Microbiol. 37: 1-15 (2014)

Rick WY, Wang T, Bedzyk L, Croker KM. Applications of DNA microarrays in microbial systems. J. Microbiol. Methods. 47: 257-272 (2001)

Ross I, Heuzenroeder M. Use of AFLP and PFGE to discriminate between Salmonella enterica serovar Typhimurium DT126 isolates from separate food-related outbreaks in Australia. Epidemiol. Infect. 133: 635-644 (2005)

Roussel Y, Colmin C, Simonet J, Decaris B. Strain characterization, genome size and plasmid content in the Lactobacillus acidophilus group (Hansen and Mocquot). J. Appl. Bacteriol. 74: 549-556 (1993)
Roy D, Ward P, Champagne G. Differentiation of bifidobacteria by use of pulsed-field gel electrophoresis and polymerase chain reaction. Int. J. Food Microbiol. 29: 11-29 (1996)

Russo R, Valletta M, Rega C, Marasco R, Muscariello L, Pedone PV, Sacco M, Chambery A. Reliable identification of lactic acid bacteria by targeted and untargeted high-resolution tandem mass spectrometry. Food Chem. 285: 111-118 (2019)

Ryu CS, Czajka JW, Sakamoto M, Benno Y. Characterization of the Lactobacillus casei group and the Lactobacillus acidophilus group by automated ribotyping. Microbiol. Immunol. 45: 271-275 (2001)

Sánchez I, Seseña S, Palop L. Polyphasic study of the genetic diversity of lactobacilli associated with 'Almagro' eggplants spontaneous fermentation, based on combined numerical analysis of randomly amplified polymorphic DNA and pulsed-field gel electrophoresis patterns. J. Appl. Microbiol. 97: 446-458 (2004)

Sattler VA, Mohnl M, Klose V. Development of a strain-specific realtime PCR assay for enumeration of a probiotic Lactobacillus reuteri in chicken feed and intestine. PLoS One 9: e90208 (2014)

Schürch A, Arredondo-Alonso S, Willems R, Goering RV. Whole genome sequencing options for bacterial strain typing and epidemiologic analysis based on single nucleotide polymorphism versus gene-by-gene-based approaches. Clin. Microbiol. Infect. 24: 350-354 (2018)

Sharma A, Kaur J, Lee S, Park YS. RAPD typing of Lactobacillus brevis isolated from various food products from Korea. Food Sci. Biotechnol. 25: 1651-1655 (2016)

Sharma A, Kaur J, Lee S, Park YS. Molecular discrimination of Lactobacillus brevis strains isolated from food products in South Korea using multilocus sequence typing. LWT-Food Sci. Technol. 86: 337-343 (2017)

Sharma A, Kaur J, Lee S, Park YS. Analysis of Leuconostoc citreum strains using multilocus sequence typing. Food Sci. Biotechnol. 27: 1755-1760 (2018a)

Sharma A, Kaur J, Lee S, Park YS. Genetic diversity analysis of Leuconostoc mesenteroides from Korean vegetables and food products by multilocus sequence typing. Appl. Microbiol. Biotechnol. 102: 4853-4861 (2018b)

Sharma A, Kaur J, Lee S, Park YS. Tracking of intentionally inoculated lactic acid bacteria strains in yogurt and probiotic powder. Microorganisms 8: 5 (2020)

Singh S, Goswami P, Singh R, Heller KJ. Application of molecular identification tools for Lactobacillus, with a focus on discrimination between closely related species: a review. LWT-Food Sci. Technol. 42: 448-457 (2009)

Spano G, Lonvaud-Funel A, Claisse O, Massa S. In vivo PCR-DGGE analysis of Lactobacillus plantarum and Oenococcus oeni populations in red wine. Curr. Microbiol. 54: 9-13 (2007)

Stachelska MA, Foligni R. Development of a time-effective and highly specific quantitative real-time polymerase chain reaction assay for the identification of Lactobacillus delbrueckii subsp. bulgaricus and Streptococcus thermophilus in artisanal raw cow's milk cheese. Acta Vet. Brno. 87: 301-308 (2018)

Stefanis C, Mantzourani I, Plessas S, Alexopoulos A, Galanis A, Bezirtzoglou E. Reviewing classical and molecular techniques regarding profiling of probiotic character of microorganisms. Curr. Res. Nutr. Food Sci. J. 4: 27-47 (2016)

Stefanovic E, Fitzgerald G, McAuliffe O. Advances in the genomics and metabolomics of dairy lactobacilli: a review. Food Microbiol. 61:33-49 (2017)

Stenico V, Michelini S, Modesto M, Baffoni L, Mattarelli P, Biavati B. Identification of Bifidobacterium spp. using hsp60 PCR-RFLP analysis: an update. Anaerobe 26: 36-40 (2014) 
Sullivan C, Jefferies J, Diggle M, Clarke S. Automation of MLST using third-generation liquid-handling technology. Mol. Biotechnol. 32: 219-225 (2006)

Sun Z, Harris HM, McCann A, Guo C, Argimón S, Zhang W, Yang X, Jeffery IB, Cooney JC, Kagawa TF. Expanding the biotechnology potential of lactobacilli through comparative genomics of 213 strains and associated genera. Nat. Commun. 6: 1-13 (2015)

Tabit FT. Advantages and limitations of potential methods for the analysis of bacteria in milk: a review. J. Food Sci.Technol. 53: $42-49$ (2016)

Tabssum F, Ahmad QuA, Qazi JI. DNA sequenced based bacterial taxonomy should entail decisive phenotypic remarks: Towards a balanced approach. J. Basic Microbiol. 58: 918-927 (2018)

Tafvizi F, Tajabadi Ebrahimi M. Application of repetitive extragenic palindromic elements based on PCR in detection of genetic relationship of lactic acid bacteria species isolated from traditional fermented food products. J. Agri. Sci. Technol. 17: 87-98 (2015)

Tanganurat W, Quinquis B, Leelawatcharamas V, Bolotin A. Genotypic and phenotypic characterization of Lactobacillus plantarum strains isolated from Thai fermented fruits and vegetables. J. Basic Microbiol. 49: 377-385 (2009)

Tynkkynen S, Satokari R, Saarela M, Mattila-Sandholm T, Saxelin $\mathrm{M}$. Comparison of ribotyping, randomly amplified polymorphic DNA Analysis, and pulsed-field gel electrophoresis in typing of Lactobacillus rhamnosus and L. casei strains. Appl. Environ. Microbiol. 65: 3908-3914 (1999)

Van Hoorde K, Vandamme P, Huys G. Molecular identification and typing of lactic acid bacteria associated with the production of two artisanal raw milk cheeses. Dairy Sci. Technol. 88: 445-455 (2008)

Vancanneyt M, Huys G, Lefebvre K, Vankerckhoven V, Goossens H, Swings J. Intraspecific genotypic characterization of Lactobacillus rhamnosus strains intended for probiotic use and isolates of human origin. Appl. Environ. Microbiol. 72: 5376-5383 (2006)

Vincent D, Roy D, Mondou F, Déry C. Characterization of bifidobacteria by random DNA amplification. Int. J. Food Microbiol. 43: 185-193 (1998)

Vinusha KS, Deepika K, Johnson TS, Agrawal GK, Rakwal R. Proteomic studies on lactic acid bacteria: a review. Biochem. Biophys. Rep. 14: 140-148 (2018)

Vos P, Hogers R, Bleeker M, Reijans M, Lee Tvd, Hornes M, Friters A, Pot J, Paleman J, Kuiper M. AFLP: a new technique for DNA fingerprinting. Nucleic Acids Res. 23: $4407-4414$ (1995)

Wang C, Han H, Gu X, Yu Z, Nishino N. A survey of fermentation products and bacterial communities in corn silage produced in a bunker silo in China. Animal Sci. J. 85: 32-36 (2014)

Wang C, Nishino N. Presence of sourdough lactic acid bacteria in commercial total mixed ration silage as revealed by denaturing gradient gel electrophoresis analysis. Lett. Appl. Microbiol. 51: 436-442 (2010)
Wang Q, Zhang X, Zhang HY, Zhang J, Chen GQ, Zhao DH, Ma HP, Liao WJ. Identification of 12 animal species meat by T-RFLP on the 12S rRNA gene. Meat Sci. 85: 265-269 (2010)

Wassenaar TM, Newell DG. Genotyping of Campylobacter spp. Appl. Environ. Microbiol. 66: 1-9 (2000)

Weckx S, Allemeersch J, Van der Meulen R, Vrancken G, Huys G, Vandamme P, Van Hummelen P, De Vuyst L. Development and validation of a species-independent functional gene microarray that targets lactic acid bacteria. Appl. Environ. Microbiol. 75: 6488-6495 (2009)

Weiss A, Lettner HP, Kramer W, Mayer HK, Kneifel W. Molecular methods used for the identification of potentially probiotic Lactobacillus reuteri strains. Food Technol. Biotechnol. 43: 295-300 (2005)

Williams JG, Kubelik AR, Livak KJ, Rafalski JA, Tingey SV. DNA polymorphisms amplified by arbitrary primers are useful as genetic markers. Nucleic Acids Res. 18: 6531-6535 (1990)

Wu B, Nishino N. Identification and isolation of Lactobacillus fructivorans from wilted alfalfa silage with and without molasses. J. Appl. Microbiol. 120: 543-551 (2016)

Wu C, Huang J, Zhou R. Genomics of lactic acid bacteria: current status and potential applications. Crit. Rev. Microbiol. 43: 393-404 (2017)

Xu H, Liu W, Zhang W, Yu J, Song Y, Menhe B, Zhang H, Sun Z. Use of multilocus sequence typing to infer genetic diversity and population structure of Lactobacillus plantarum isolates from different sources. BMC Microbiol. 15: 241 (2015)

Yu D, Shi K, Wen X, Xie F, Wang T, Liu S, He L. Evidence of the genetic diversity and clonal population structure of Oenococcus oeni strains isolated from different wine-making regions of China. J. Microbiol. 56: 556-564 (2018)

Zheng J, Ruan L, Sun M, Gänzle M. A genomic view of lactobacilli and pediococci demonstrates that phylogeny matches ecology and physiology. Appl. Environ. Microbiol. 81: $7233-7243$ (2015)

Zheng J, Wittouck S, Salvetti E, Franz CMAP, Harris HMB, Mattarelli P, O'Toole PW, Pot B, Vandamme P, Walter J, Watanabe K, Wuyts S, Felis GE, Gänzle MG, Lebeer S. A taxonomic note on the genus Lactobacillus: Description of 23 novel genera, emended description of the genus Lactobacillus Beijerinck 1901, and union of Lactobacillaceae and Leuconostocaceae. Int. J. Syst. Evol. Microbiol. 70: 2782-2858 (2020)

Zhong W, Millsap K, Bialkowska-Hobrzanska H, Reid G. Differentiation of Lactobacillus species by molecular typing. Appl. Environ. Microbiol. 64: 2418-2423 (1998)

Publisher's Note Springer Nature remains neutral with regard to jurisdictional claims in published maps and institutional affiliations. 